\title{
Effect of Tax-Related Information on Pre-Tax Income Forecast and Value Relevance
}

\author{
Kwang-Wuk $\mathrm{OH}^{1}$, Eun-Sun $\mathrm{KI}^{2}$
}

Received: September 08, 2019 Revised: October 12, 2019 Accepted: November 15, 2019

\begin{abstract}
We examine the effects of the complexity of tax-related information on the issuance of analyst's pre-tax income forecast and its value relevance. If analysts respond adequately to the needs of investors, they are more likely to provide a pre-tax income forecast. The provision of a pre-tax income forecast may indicate analysts' confidence in assessing the quality of earnings. Thus, investors, in turn, would be more confident in the analysts' pre-tax income forecasts if analysts provide both pre-tax and earnings forecasts than only the latter. Using a sample of Korean listed companies for 2005-2014, we find that analysts are likely to provide an implicit tax forecast when the volatility of the effective tax rate is low and the book-tax differences are small. We also find that when analysts provide pretax and after tax income forecasts, the value relevance for unexpected earnings increases. These results indicate that analysts are likely to be interested in corporate tax information and the complexity of tax-related information affects the availability of implicit tax forecasts. Furthermore, this study provides empirical evidence that when analysts provide both pre-tax and after tax income forecasts, investors have more confidence in analysts' earnings forecasts, which results in greater investors' responses.
\end{abstract}

Keywords : Book-Tax Differences, Effective Tax Rate, Earnings Response Coefficient, Pre-Tax Income Forecast, Value Relevance

JEL Classification Code : M41, M42, G24

\section{Introduction}

In this study, we investigate whether the complexity of tax forecasts affects the forecasts of tax expense and the issuance of analyst's pre-tax income forecast enhances value relevance. That an investor accurately predicts the corporate tax expense may indicate that additional tax-related information can help identify and restrain earnings management by a manager. The investor reaction to corporate tax information shows that investors initially

1 First Author, Associate Professor, Korea University College of Global Business, South Korea. Email: avnini92@korea.ac.kr

2 Corresponding Author, Associate Professor, Division of Business Administration and Accounting, Kangwon National University, South Korea. [Postal Address: Business Administration Bld., Room 406, KangwonDaehak-gil, Chuncheon, Gangwon-do, 23431, South Korea] Tel. +82-33-250-6174, Fax. +82-33-259-5531, Email: eski@kangwon.ac.kr

(c) Copyright: Korean Distribution Science Association (KODISA)

This is an Open Access article distributed under the terms of the Creative Commons Attribution Non-Commercial License (http://Creativecommons.org/licenses/by-nc/4.0/) which permits unrestricted noncommercial use, distribution, and reproduction in any medium, provided the original work is properly cited. underreact to the information that corporate tax expense implies about future earnings but later fully respond when these earnings are subsequently realized (Thomas \& Zhang, 2011). This implies that the investor reaction can be related to the complexity and uncertainty of tax information. Providing information on corporate taxes additionally contributes to the capital market. For example, Baik, Kim, Morton and Roh (2016) tested whether analysts' tax-related forecasts (implicit tax forecasts) alleviate informational risks from the complexity and obscurity of tax expenses. Their research implies that the information related to tax expense plays a role in the interpretation of accounting information by investors and the prediction of the future outlook. We expand on extant research by examining whether the complexity of tax-related information innate in financial statements affects financial analysts' pre-tax income forecast propensity. After controlling for endogeneity in the propensity of the forecast for pre-tax income, we test the incremental value relevance of accounting information when pre-tax income forecasts are provided. 
In Korea, the calculation of taxable income starts from net income (loss) by adjusting accounting records according to the corporate tax act. In this regard, the Korean corporate tax system linked to financial accounting (one book system) is appropriate for examining managerial decisions on tax burden by accounting choice. Also, it offers a better research setting to examine the propensity of analysts to provide a forecast on tax-related information and its incremental impact on value relevance. Since information on the actual tax burden is still not publicly available, we expect the implicitly forecasted tax-related information by professional analysts to potentially help market participants sufficiently understand firms with complex and uncertain tax-related information.

An attribute of information such as complexity affects how efficiently market participants use that information in two ways. First, an increase in complexity adversely limits the use of information by market participants. Specifically, task complexity impairs judgment through strategy selection of decision makers, where a strategy is the method or set of procedures that an individual use to incorporate information into decision-making (Payne, 1976; Bettman, Johnson, \& Payne, 1990). Consequently, when the complexity of tasks associated with the use of information is high, the decision maker uses a simpler strategy, which leads to incomplete use of available information. Second, the complexity of information also makes it difficult for financial analysts to assimilate it. Prior research (Hisrt \& Hopkins, 1998; McEwen \& Hunton, 1999) indicate that providing investors with additional information, such as corporate tax with high task complexity, incrementally contributes to more accurate interpretation and rational prediction of firms, which, in turn, increases the value relevance. To explore the value of taxrelated information in the Korean tax system, we examine whether the complexity of information in financial statements related to corporate tax is taken into account in analysts' decision-making process, especially with respect to providing or not providing forecasts related to pre-tax income.

As extended research on the impact of tax-related information, we adopt the earnings response coefficient (ERC) model to examine the incremental magnitude of earnings surprise to abnormal return. If the pre-tax forecast is value-relevant, it is expected to have an incremental impact on the coefficient estimate of unexpected earnings to the abnormal return. To check the role of the pre-tax forecast according to the information environment, we test the differentiated impact in the value relevance of pre-tax forecast information according to the degree of the complexity and uncertainty of tax-related information innate in financial statement.

Our study contributes to extant literature in numerous ways. First, this study shows that the analysts are likely to be interested in corporate tax information contrary to Plumlee (2003) who argues that analysts do not deeply understand taxes. As an extension of extant literature, we provide empirical evidence to show that analysts practice discriminatory decision-making on whether or not to provide pre-tax income forecasts according to the complexity and uncertainty of tax-related information innate in financial statements. Second, this study shows that in Korea, where accounting transparency is known to be low by high interface between accounting and taxes (Joos \& Lang, 1994; Ali \& Hwang, 2000; Hanlon, Maydew, \& Shevlin, 2005; Hanlon, Laplante, \& Shevlin, 2006), implicit tax expense forecasts by sophisticated information intermediaries such as financial analysts can help investors' understanding in terms of the value relevance of accounting information. Third, the study provides empirical evidence on difference in information usefulness of the pre-tax income forecast according to tax information complexity. As mentioned previously, tax expense may be an important means of adjusting earnings (Dhaliwal, Gleason, \& Mills, 2004), which increases earnings to meet target performance. Information related to tax expense has a role in investors' interpretation of accounting information (Baik et al., 2016). Therefore, if investors are provided with credible tax-related forecast information, which can be inferred from both pretax income and earnings forecasts, it could help them predict accurate earnings.

\section{Literature Review \& Hypotheses}

\subsection{Determination of corporate taxable income in Korea}

In Korea, taxable income (loss) is closely related to the net income (loss) in financial accounting. However, the matters separately stipulated in the corporate tax act take precedence over the provisions of the Generally Accepted Accounting Principles (GAAP). There are three types of GAAP in Korea. First, K-IFRS is applied to public entities. Second, for non-public entities, statutory accounting standards are applied. Finally, for small and medium entities (SME) that are exempted from the mandatory external audit, the accounting standard for SME is applied. Specifically, there are two ways of calculating corporate taxable income in Korea: the case where there is no difference from the GAAP (the matters not stipulated in the corporate tax act) and case where there are differences from the GAAP (the matters separately stipulated in the corporate tax act). More specifically, for financial accounting records which are not separately stipulated in the corporate tax act, no differences between financial accounting and tax accounting and the effect on profit and loss are equally reflected in taxable income. Thus, the profits and losses determined in the financial accounting are also considered profits and losses in tax accounting.

Major examples of adjustments to yield corporate taxable income are as followings (Appendix presents the process of calculating corporate taxable income and articles in Korea corporate tax act). First, if the properties of 
amounts in the financial statements are an estimate (e.g., valuation allowances, provisions for loss reserves and allowance for bad debts, etc.), such amounts are not accepted, and are reverted in taxable income. Second, if the corporate tax act stipulates special treatment in determining taxable income that allows taxpayers to defer tax payment, they are treated as a reduction of taxable income. Third, if the values of assets and liabilities in a financial statement are different from those accepted in the corporate tax act, the differences will be reflected as an adjustment (addition or deduction) to taxable income. Fourth, as an example of permanent differences, the corporate tax act does not accept as expense that which exceeds the limit stipulated in the corporate tax act in order to prevent incentives to lower taxable income through excessive expenses, such as depreciation, donations, entertainment, and non-business expenses. As shown in the examples above, the corporate taxable income in Korea is determined through the adjustment process that increases or decreases the net income (loss) of the income statement. Correspondingly, firms do not need to have a separate book to determine corporate taxable income. Indeed, taxable income is calculated through an adjustment process based on accounting books in accordance with the provisions of the corporate tax act.

The process of calculating taxable income in Korea offers unique research opportunities. Specifically, the singlebook system overlaps most of the taxable income (loss) with profit (loss) in financial accounting. However, it only adjusts differences with the corporate tax act. This system can be advantageous for efficiency of tax administration costs. Nevertheless, it could lead to a negative impact on the transparency of accounting information because managers can easily consider accounting choices by bearing in mind taxable income. Several studies (Ali \& Hwang, 2000; Hanlon et al. 2005) suggest that high interface between accounting and taxation may result in lower value relevance of accounting information because government needs would likely influence accounting practices. In this vein, we theorize that Korea, with a single book system, will have low value relevance of accounting information. Thus, analysts' tax-related information may incrementally contribute to value relevance because the provision of implicitly inferred tax information from analysts may help investors' interpretation of accounting information.

\subsection{Managing earnings using tax expenses and impact of pre-tax income forecasts}

The association between earnings management using corporate tax expenses and corporate tax strategy is well known. This implies that a manager concurrently makes decisions related to tax costs in managing accounting profit. According to Dhaliwal et al. (2004), when earnings before manipulation fall below the target, managers are likely to adjust earnings using the corporate tax expense. Gleason and
Mills (2008) observed a negative market response when managers cut their corporate tax expenses in the fourth quarter to meet the target earnings. Extending Dhaliwal et al. (2004)'s study, Cook, Huston, and Omer (2008) showed that the tax service fees paid to auditors are related to ETR changes in the third-to-fourth quarter, assuming that the tax fees paid to auditors will affect both taxable and financial income. Taken together, extant studies consistently report that managers have incentives to consider tax factors in accounting decisions, and are likely to pay attention for balancing their decision between financial and tax accounting.

\subsection{Hypotheses}

\subsubsection{Propensity of analyst forecast}

Financial analysts show discriminatory behavior in providing information such as corporate tax expense. Plumlee (2003) found that analysts' revisions of their forecasts of effective tax rates appear to be more sensitive to less complex tax law revisions than more complex ones. The empirical results of prior research (Hirst \& Hopkins, 1998; McEwen \& Hunton, 1999; Defond \& Hung, 2003) allow us to conclude that analysts are responding appropriately to the needs of investors when they believe that additional forecasting information is useful in assessing the quality of earnings.

Plumlee (2003) suggests that analysts may struggle to incorporate tax effects in their EPS forecasts. Specifically, they report that analysts' forecasting accuracy tend to be dampen around changes in tax law. Shane and Stock (2006) find that analysts do not incorporate inter-temporal shifting from high tax rate to low tax rate during the fiscal year. Weber (2009) reports that analysts' deviation from actual EPS are positively associated with book-tax differences (BTD) and Amir and Sougiannis (1999) observe that analysts' EPS forecasts error is large for firms with tax-loss carryforwards. Recently, Bratten, Gleason, Larocque, and Mills (2017) find that relative to management, analysts pay high attention to the tax related information and show that they incorporate and improve managers' ETR forecasts.

From finding of studies, we may accordingly infer that analysts are responsive to information properties, and that investor demands and tax expenses can be related. Thus, our first hypothesis tests whether an analyst provides investors with pre-tax income forecast information according to the degree of the complexity of tax-related information innate in financial statements. Complexity adversely limits the use of information by market participants (Payne, 1976; Bettman et al., 1990); similarly, if complexity of information makes it difficult for analysts to assimilate information (Hirst \& Hopkins, 1998; McEwen \& Hunton, 1999), they will provide investors with tax-related forecasts for firms with less complex tax-related information in financial statements.

H1: Ceteris paribus, the possibility of providing analysts' forecasts of pre-tax income forecast will increase when the tax-related information of firms is less complicated. 


\subsubsection{Informational contents of tax-related information}

As important information related to corporate tax expenses, book-tax differences (BTDs) are known to be useful for capital market participants to predict future earnings and to evaluate stock value. For example, Lev and Nissim (2004) found that BTDs can predict future stock returns. However, their findings also imply that investors possibly fail to fully appreciate the information on stock prices. In addition to BTDs, many extant studies use the tax expense account and estimated taxable income to examine usefulness of BTDs to equity investors, such as profitability (Ayers, Jiang, \& Laplante, 2009; Weber, 2009) and corporate risk (Dhaliwal, Lee, Pincus, \& Steele, 2017; Henry, 2017) incremental to GAAP income. Based on the aforementioned findings of extant studies, we can conclude that tax-related information is relevant to firm value and incremental information to predict future performance; further, it is associated with systematic firm risks.

Recent studies provide empirical evidence on managers' reaction to meet market expectation and analysts' provision of implicit tax expenses to examine their impact on the capital market (Baik et al., 2016; Gupta, Laux, \& Lynch, 2016). Gupta et al. (2016) used pre- and post-tax earnings to impute pre-managed earnings; they found that managers are likely to reduce tax reserve to meet analyst forecasts, which are more pronounced in pre- than post-FIN48. FIN 48 requires companies to analyze and disclose income tax risks since 2007. Baik et al. (2016) paid attention to financial analysts' additional provision of pre-tax forecast, and found that implicit tax forecast draws investor attention to tax expense accounts.

Hanlon et al. (2005) suggest that in spite of tax expenses which are negative impact on net income, taxable income may indicate incremental signal of future performance that is incompletely appreciated by market participants. From findings by Call, Chen, and Tong (2009) and Radhakrishnan and $\mathrm{Wu}$ (2014) that analysts' forecast accuracy is positively coupled with items of forecasts, we may infer that additional provision of tax-related information affects investors' concerns about firms' future performance and draw attention to tax information. As results, we expect that investors' care for current tax expenses and their implications innated in tax-related information will be impounded in stock price. Our second hypothesis thus tests the incremental value of earnings surprise when a pre-tax income forecast is provided, is greater than when only the earnings forecast is provided, after controlling endogeneity related to analysts' decision to provide pre-tax income forecasts.

H2: Ceteris paribus, analysts' implicit tax forecast information has a positive (+) incremental effect on the ERC.

\section{Research Design}

\subsection{Sample}

A sample of the study consists of Korean listed companies for 2005-2014, and satisfies the following conditions:

- Non-financial companies

- Companies with a fiscal year-end of December

- Companies with earnings forecasts and stock return data in DataGuide (DataGuide is database comparable to $\mathrm{I} / \mathrm{B} / \mathrm{E} / \mathrm{S}$ in the U.S.)

- Companies with financial data and stock price data in KIS Value III (KIS Value III is database comparable to Compustat in the U.S.)

- $\quad$ Companies with positive earnings forecasts

DataGuide began to provide analysts' forecast data for the target year 2005 of selected firms listed companies in Korea. Also, we could not use private firms in our tests since ERC model (Eq. 2) uses abnormal stock return data available only for the listed firms.

Table 1 presents our sampling criteria. We exclude financial firms from the sample because financial firms have different forms of financial statements and accounts with other companies. To control the difference in the fiscal yearend, we use only the companies whose year-end is December 31. We obtain pre-tax income forecasts, earnings forecasts, and stock return data from DataGuide, and financial data from KIS Value III. We also exclude companies with negative earnings forecasts because loss companies do not have a corporate income tax to pay. After this sampling process, we select 2,972 firm-year observations as a final sample. Our data is winsorized by $1 \%$ at the top and bottom of each continuous variable to reduce distortion due to outliers and to avoid sample loss.

Table 1: Sample Selection

\begin{tabular}{|l|r|}
\hline \multicolumn{1}{|c|}{ Sample selection criteria } & $\begin{array}{c}\text { No. of firm- } \\
\text { year } \\
\text { observations }\end{array}$ \\
\hline As of May 1, earnings forecasts for year $t$ & 3,154 \\
\hline Less: & $(-) 68$ \\
\hline Observations with a loss forecast & $(-) 74$ \\
\hline $\begin{array}{l}\text { Observations without tax-related information } \\
\text { (ETR, VolETR, and VolBTD) }\end{array}$ & $(-) 37$ \\
\hline Observations without other financial data & $(-) 3$ \\
\hline Observations without return data & 2,972 \\
\hline Final sample & 2,329 \\
\hline \multicolumn{2}{|l|}{ Earnings and pre-tax income forecasts } \\
Earnings forecast without pre-tax income \\
\hline $\begin{array}{l}\text { The sample consists of 2,972 publicly traded companies in Korea } \\
\text { with financial analyst forecasts. }\end{array}$ \\
\hline \multicolumn{2}{|l}{} \\
\hline
\end{tabular}

Table 2 shows the distribution of samples by industry and by year. In Panel A, of the 2,972 after-tax forecasts, $78.4 \%$ are supplemented by pre-tax forecasts. The ratio of analysts issuing pre-tax forecasts dropped from $87 \%$ in 2005 to $63 \%$ in 2010 , but steadily increased since the adoption of new accounting standards, International Financial Reporting 
Standards, reaching $91 \%$ in 2014. Panel B presents the sample distribution by industry. The industry with the largest share in the sample is manufacturing, accounting for $64.3 \%$ of the total sample; $73.5 \%$ of after-tax forecasts in manufacturing are supplemented by pre-tax income forecasts. Panel $\mathrm{C}$ shows the provision of supplementary forecasts. Moreover, $99.9 \%$ and $98.5 \%$ of the sample with earnings forecasts has sales forecasts and operating income forecasts, respectively, but only $78.4 \%$ has pre-tax forecasts.

Table 2: Sample Distribution

\begin{tabular}{|c|c|c|c|c|c|}
\hline Panel A: Yearly sample distribution \\
\hline & Total & \multicolumn{2}{|c|}{$\begin{array}{c}\text { Earnings and pre- } \\
\text { tax income } \\
\text { forecasts }\end{array}$} & \multicolumn{2}{|c|}{$\begin{array}{c}\text { Earnings } \\
\text { forecast without } \\
\text { pre-tax income } \\
\text { forecast }\end{array}$} \\
\hline 2005 & 332 & 290 & $87 \%$ & 42 & $13 \%$ \\
\hline 2006 & 380 & 305 & $80 \%$ & 75 & $20 \%$ \\
\hline 2007 & 372 & 293 & $79 \%$ & 79 & $21 \%$ \\
\hline 2008 & 326 & 221 & $68 \%$ & 105 & $32 \%$ \\
\hline 2009 & 304 & 224 & $74 \%$ & 80 & $26 \%$ \\
\hline 2010 & 344 & 217 & $63 \%$ & 127 & $37 \%$ \\
\hline 2011 & 334 & 248 & $74 \%$ & 86 & $26 \%$ \\
\hline 2012 & 222 & 201 & $91 \%$ & 21 & $9 \%$ \\
\hline 2013 & 221 & 206 & $93 \%$ & 15 & $7 \%$ \\
\hline 2014 & 137 & 124 & $91 \%$ & 13 & $9 \%$ \\
\hline Total & 2,972 & 2,329 & & 643 & \\
\hline
\end{tabular}

\begin{tabular}{|l|c|c|}
\hline \multicolumn{1}{|c|}{ Industry Classification } & $\begin{array}{c}\text { Earnings and } \\
\text { pre-tax } \\
\text { income } \\
\text { forecasts }\end{array}$ & $\begin{array}{c}\text { Earnings } \\
\text { forecast } \\
\text { without pre- } \\
\text { tax income } \\
\text { forecast }\end{array}$ \\
\hline $\begin{array}{l}\text { Agriculture, forestry, and } \\
\text { fishing }\end{array}$ & 3 & 2 \\
\hline Manufacturing & 1,440 & 472 \\
\hline $\begin{array}{l}\text { Electricity, gas, steam, and air } \\
\text { conditioning supply }\end{array}$ & 31 & 6 \\
\hline $\begin{array}{l}\text { Sewerage, waste } \\
\text { management, water supply, } \\
\text { and remediation activities }\end{array}$ & 1 & 3 \\
\hline Construction & 118 & 14 \\
\hline Wholesale and retail trade & 150 & 36 \\
\hline $\begin{array}{l}\text { Information and } \\
\text { communication }\end{array}$ & 212 & 73 \\
\hline Transportation and storage & 44 & 3 \\
\hline $\begin{array}{l}\text { Accommodation and food } \\
\text { service activities }\end{array}$ & 3 & 1 \\
\hline Real estate activities & 1 & 0 \\
\hline $\begin{array}{l}\text { Professional, scientific, and } \\
\text { technical activities }\end{array}$ & 229 & 24 \\
\hline $\begin{array}{l}\text { Administrative and support } \\
\text { service activities }\end{array}$ & 29 & 5 \\
\hline Education & 36 & 2 \\
\hline $\begin{array}{l}\text { Arts, entertainment, and } \\
\text { recreation }\end{array}$ & 10 & 29 \\
\hline Other service activities & & 53 \\
\hline Total & 292 & 2 \\
\hline
\end{tabular}

\begin{tabular}{|l|c|c|}
\hline \multicolumn{1}{|c|}{ Panel C: provision of supplementary forecasts } \\
\hline Type & $\begin{array}{c}\text { Number of } \\
\text { forecasts }\end{array}$ & $\%$ \\
\hline Earnings forecast & 2,972 & 100.0 \\
\hline Sales and earnings forecasts & 2,970 & 99.9 \\
\hline
\end{tabular}

\begin{tabular}{|c|c|c|}
\hline Operating income and earnings forecasts & 2,927 & 98.5 \\
\hline Pre-tax income and earnings forecasts & 2,329 & 78.4 \\
\hline
\end{tabular}

\subsection{Methodology}

Financial analysts' provision of pre-tax income has selfselection problem by factors that affect their forecasting propensity. Thus, to test $\mathrm{H} 1$ and to obtain consistent coefficient estimates on instrumental variables (Heckman, 1979), we use the following logit model:

$$
\begin{aligned}
& T A X F_{i t}=\alpha_{0}+\alpha_{1} \text { ETR }_{i t}+\alpha_{2} \text { VolETR }_{i t}+\alpha_{3} \text { BTD }_{i t} \\
& +\alpha_{4} \text { VolBTD }_{i t}+\alpha_{5} \text { SIZE }_{i t} \\
& +\alpha_{6} R O A_{i t}+\alpha_{7} \text { PERM } \\
& +\alpha_{8} \text { CapInt }_{i t}+\alpha_{9} \text { VolEarning }_{i t} \\
& + \text { Year dummies } \\
& + \text { Industry dummies }+\varepsilon_{i t}
\end{aligned}
$$

In Eq. (1), the dependent variable, TAXF, is an indicator variable whose value is 1 if a financial analyst provides both pre-tax income and earnings forecast, 0 otherwise. The main variables of interest are VolETR, BTD, and VolBTD. The coefficients of $\alpha 2, \alpha 3$, and $\alpha 4$ are expected to be negative if the likelihood that a financial analyst will provide a pre-tax income forecast decreases with the uncertainty of the taxrelated information.

We include tax-related information innate in financial statements such as effective tax rate (ETR) and book-tax differences (BTD) that are expected to affect analysts' provision of pre-tax income forecasts. Bhushan (1989), Bhushan and O'Brien (1900), Park and Yoo (2019) argue that investors invest more in large companies, and the larger 
the size of the companies, the higher the information demand. As a result, investors are likely to trade for large companies on the basis of financial analyst information. McNichols and O'Brien (1997) suggest that analyst tend to issue forecasts for profitable firms, however, high volatility in performance makes it difficult for analysts to accurately forecast. Following these prior studies, we add firm size (SIZE, CapInt), profitability (ROA and PERM), and its volatility (VolEarnings) to the model (Jeong \& Park, 2016; Lee \& Lee, 2018; Chae \& Ryu, 2018).

If the provision of a pre-tax income forecast plays a role in raising the investor's confidence in analysts' earnings forecasts, the stock price reaction to unexpected earnings will be noticeable when an analyst provides both pre-tax income and earnings forecasts. To test $\mathrm{H} 2$, we use the following two-step regression model:

First stage:

$$
\begin{aligned}
\text { TAXF }_{i t}=\alpha_{0}+ & \alpha_{1} \text { ETR }_{i t}+\alpha_{2} \text { VolETR }_{i t}+\alpha_{3} \text { BTD }_{i t} \\
& +\alpha_{4} \text { VolBTD }_{i t}+\alpha_{5} \text { SIZE }_{i t} \\
& +\alpha_{6} \text { ROA }_{i t}+\alpha_{7} \text { PERM }_{i t} \\
& +\alpha_{8} \text { CapInt }_{i t}+\alpha_{9} \text { VolEarnings }_{i t} \\
& + \text { Year dummies } \\
& + \text { Industry dummies }+\varepsilon_{i t}
\end{aligned}
$$

Second stage:

$$
\begin{aligned}
R E T_{\_} v w_{i t}\left(R E T_{-} e w_{i t}\right) & \\
& =\beta_{0}+\beta_{1} U E_{i t}+\beta_{2} \text { predTAXF }_{i t} \\
& +\beta_{3} U E_{i t} \times \text { predTAXF } F_{i t}+\varepsilon_{i t}
\end{aligned}
$$

predTAXF = Predicted value of TAXF estimated using the first stage model;

$R E T_{-} v w=$ Equally weighted size-adjusted returns for 12 months starting from the fourth month after the end of the year $(\mathrm{t}-1)$;

RET_ew = Value weighted size-adjusted returns for 12 months starting from the fourth month after the end of the year (t-1);

UE $\quad=$ (Consensus earnings forecast for year $\mathrm{t}$ as of May 1 - reported earnings for year t)/beginning-of-the-year market value.

As mentioned above, we test $\mathrm{H} 2$ by employing a twostep regression model to address this endogeneity. First, we use Eq. (1) to estimate the probability that a financial analyst will provide a pre-tax income forecast. In the second stage, we examine whether or not the relationship between unexpected earnings and abnormal market returns depends on the provision of a pre-tax income forecast by adopting earnings response coefficients (ERC) model in early researches such as Kormendi and Lipe (1987) and Collins and Kothari (1989) testing one-to-one link between unexpected earnings and stock return. By expanding ERC model, we test $\mathrm{H} 2$ from coefficient estimates on incremental effects of PredTAXF*UE on stock returns (RET_ew, RET_vw). If an implicit tax forecast plays a role in raising the investor's confidence in analysts' earnings forecasts, $\beta 3$ is expected to be positive. To test our hypotheses, we construct a simple model of the price reaction to the signal (i.e. tax information) following Kothari (2001) and Hanlon et al. (2005).

\section{Empirical Results}

\subsection{Summary Statistics}

Descriptive statistics are represented in Table 3. According to columns 2 and 3 of Table 3, the mean (median) values of ETR, SIZE, CapInt, and UE are 0.18(0.22), 27.11(26.86), $0.30(0.28)$, and $0.04(0.02)$, respectively, in the sample of earning and pre-tax income forecasts $(\mathrm{N}=2,329)$, while they are $0.13(0.19), 25.65(25.44), 0.27(0.26)$, and $0.07(0.04)$, respectively, in the sample of earnings forecast without the pre-tax income forecast $(\mathrm{N}=643)$.

Column 4 of Table 3 shows univariate test results that examines the mean difference between the two groups. For example, the mean values of ETR, SIZE and Caplint in the firm-year sample of earning and pre-tax income forecasts $(\mathrm{N}=2,329)$ are larger than those of the firm-year sample of earnings forecast without the pre-tax income forecast $(\mathrm{N}=643)(0.05,1.46$, and 0.03 , respectively, and significant at the $5 \%$ level at least). Thus, analysts are more likely to provide a pre-tax income forecast along with earnings forecast for large firms with high effective tax rate and capital intensity.

Table 3: Descriptive Statistics and Univariate Test $(\mathrm{N}=2,972)$

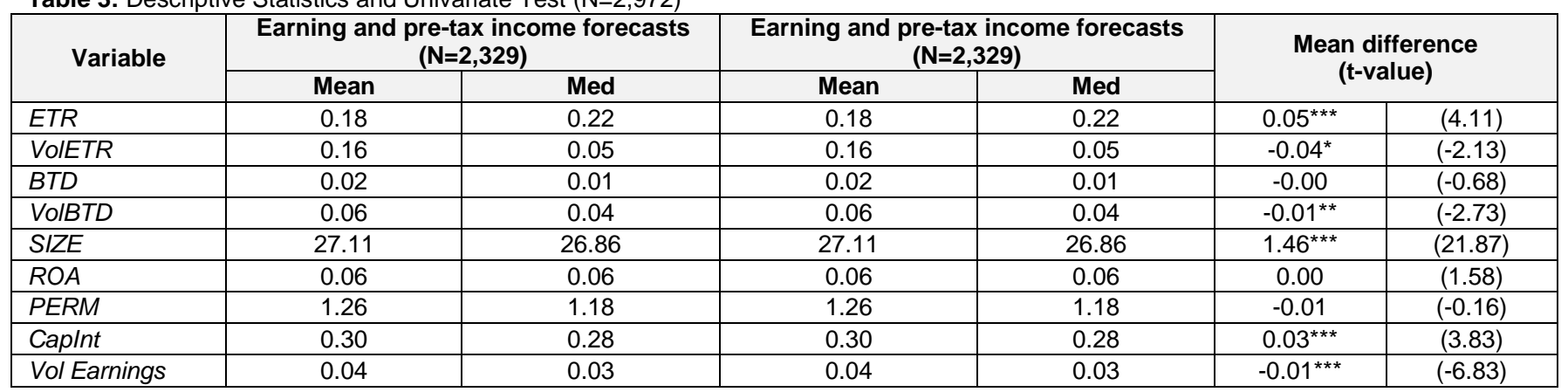




\begin{tabular}{|l|c|c|c|c|c|c|}
\hline UE & -0.04 & -0.02 & -0.04 & -0.02 & $0.03^{\star * *}$ & $(5.47)$ \\
\hline$R E T \_v w$ & 0.04 & -0.06 & 0.04 & -0.06 & -0.02 & $(-0.79)$ \\
\hline$R E T \_e w$ & 0.04 & -0.06 & 0.04 & -0.06 & -0.02 & $(-1.04)$ \\
\hline 1) Refer to Eq. (1) \& (2) for the variable definitions. The sample consists of 2,972 publicly traded companies in Korea with financial analyst
\end{tabular}

forecasts. ${ }^{*},{ }^{* \star}$, and ${ }^{* * *}$ represent significance at a $10 \%, 5 \%$, and $1 \%$ level (two-sided), respectively.

Table 4 shows the correlation matrix. In this result, the correlation among variables shows that analysts are responsive to the information properties and investor demand. The correlations among the explanatory variables are modest, except for UE, BTD, ROA, RET_vw, and
RET_ew $(0.48,0.66,0.28$, and 0.28 , respectively). Our checks of the variance inflation factor (VIF) among variables show that the multicollinearity problem is not serious.

Table 4: Pearson Correlation Matrix ( $\mathrm{N}=2,972)$

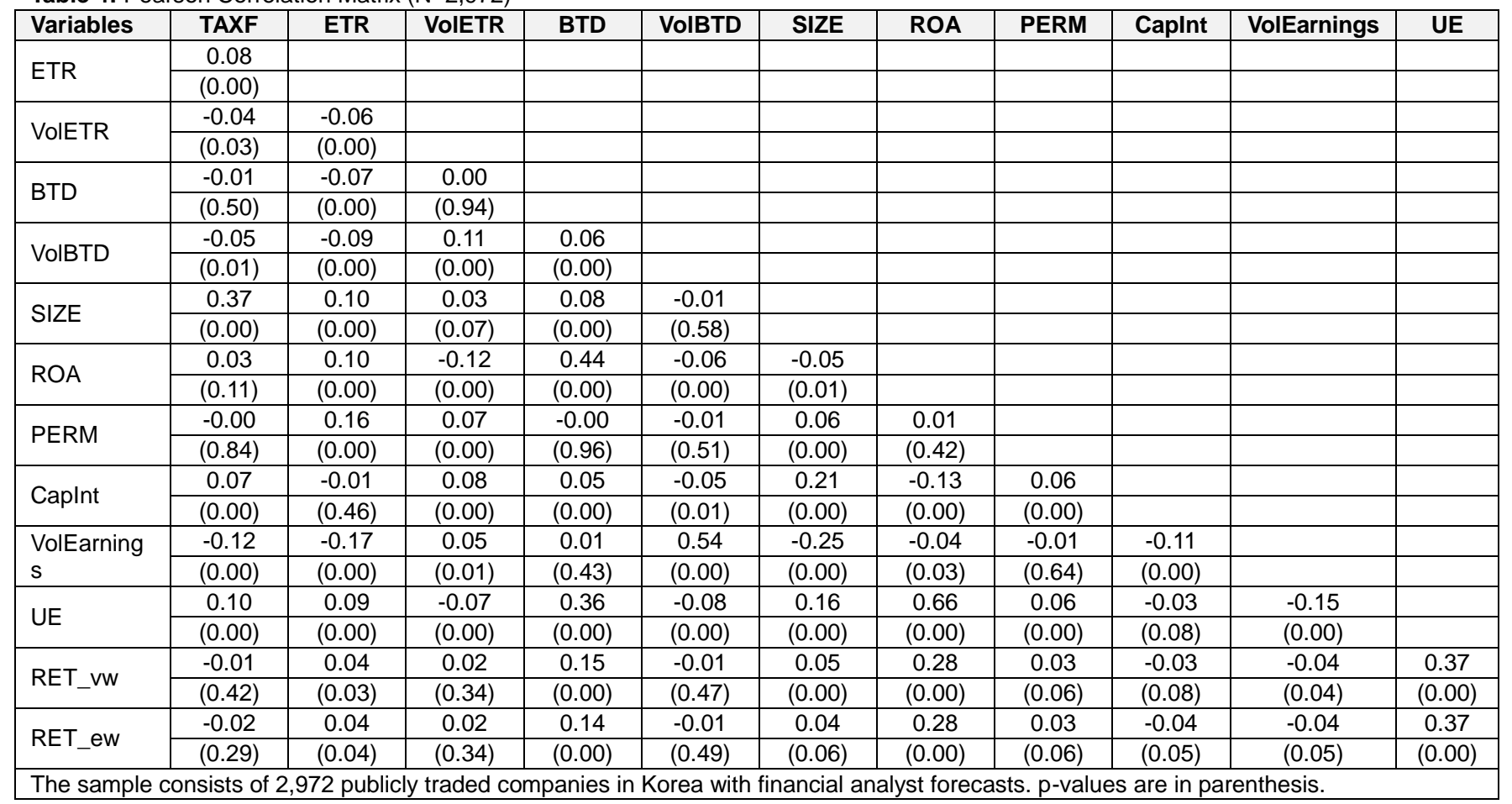

\subsection{Multivariate Test Results}

\subsubsection{Results of H1: Analysts' pre-tax income forecast propensity}

Table 5 presents the logit analysis results for analysts' pre-tax income forecasts. All key variables of interest that are proxies for complexity of information are consistently negative and statistically significant for the dependent variable (TAXF). For example, the results by separate key variables (VolETR, BTD, and VolBTD) from model 1 to model 3 (columns 2-4) show consistently negative coefficient estimates on TAXF at the $10 \%$ significance level at least $(0.32$ for VolETR, 1.65 for BTD, and 2.01 for VolBTD, respectively).

We also obtain consistent results with model 4 (column 5) when incorporating all key variables. Specifically, the coefficient estimates of VolETR, BTD, and VolBTD on TAXF are still $0.29,1.51$, and 1.67 , respectively, and significantly negative. Thus, analysts are less willing to provide pre-tax income forecasts for firms with a high degree of complexity in corporate tax information, such as volatility of ETR and BTDs (BTD and VolBTD). Accordingly, consistent with extant research-that complexity adversely limits the use of information by market participants (Payne, 1976; Bettman et al., 1990) analysts tend to additionally provide investors with a taxrelated forecast (which can be used from the difference between pre-tax income and earnings) for firms with less complex tax-related information in their financial statements. From the findings in Table 5, we can conclude that $\mathrm{H} 1$ is consistently supported. 
Table 5: Logit Analysis - Effect of Complexity of Tax-related Information

\begin{tabular}{|c|c|c|c|c|c|}
\hline Variables & Sign & Model 1 & Model 2 & Model 3 & Model 4 \\
\hline ETR & + & & & & 0.00 \\
\hline \multirow{2}{*}{ VolETR } & \multirow{2}{*}{-} & $-0.32^{*}$ & & & $-0.29^{*}$ \\
\hline & & $(-2.52)$ & & & $(-2.28)$ \\
\hline BTD & - & & $-1.65^{*}$ & & $-1.51^{*}$ \\
\hline VolBTD & - & & & $(-1.95)$ & $(-1.61)$ \\
\hline \multirow{2}{*}{ SIZE } & \multirow{2}{*}{+} & $1.09^{\star * *}$ & $1.10^{\star \star \star}$ & $1.10^{\star \star \star}$ & $1.11^{* \star *}$ \\
\hline & & $(17.93)$ & (17.97) & $(17.93)$ & $(17.92)$ \\
\hline \multirow[b]{2}{*}{ ROA } & \multirow[b]{2}{*}{+} & 0.99 & $2.18^{* *}$ & 1.12 & $1.88^{*}$ \\
\hline & & $(1.47)$ & $(2.73)$ & $(1.66)$ & $(2.32)$ \\
\hline PERM & + & -0.05 & -0.05 & -0.05 & -0.05 \\
\hline VolEarnings & - & $(0.46)$ & $(0.57)$ & (1.49) & $(1.52)$ \\
\hline Year dummy & $+/-$ & Yes & Yes & Yes & Yes \\
\hline Industry dummy & $+/-$ & Yes & Yes & Yes & Yes \\
\hline \multicolumn{2}{|l|}{$\mathrm{N}$} & 2,972 & 2,972 & 2,972 & 2,972 \\
\hline \multicolumn{2}{|l|}{ Wald $X^{2}$} & $845.6^{* \star *}$ & $845.2^{\star \star *}$ & $843.4^{\star \star *}$ & $853.2^{\star \star \star}$ \\
\hline \multicolumn{2}{|l|}{ Pseudo $\mathrm{R}^{2}$} & 0.27 & 0.27 & 0.27 & 0.28 \\
\hline
\end{tabular}

\subsubsection{Results of H2: Incremental impact of analysts' pre-tax forecast on the ERC}

Table 6 shows the results of $\mathrm{H} 2$, which tests the incremental impact of a pre-tax income forecast on the ERC of earnings surprise (UE). As mentioned previously, to control the selection bias by analysts who are likely to issue pre-tax income forecast information according to the complexity of tax-related information, we employee a twostage regression estimation approach. Specifically, based on the results in Table 5, we obtain a predictive variable (predTAXF) indicating analysts' propensity from the logit equation, Eq. (1), and then use the instrumental variable (predTAXF) in Eq. (2) for the dependent variables (RET_vw and RET_ew, respectively). To examine the incremental effect of tax expense forecasts on ERC (value relevance), we check the statistical significance of the intersection variable, UE and predTAXF (UE*predTAXE).

As shown in Table 6, the baseline variable, UE, shows consistently positive coefficient estimates (1.113 and 1.177, respectively) on the dependent variables (RET vw and RET ew, respectively) at the $1 \%$ significance level at least. Thus, investors positively react for earnings surprise (UE) regardless of measurement of size-adjusted return.

Consistent with $\mathrm{H} 2$, we observe an incremental impact of the propensity of the provision of pre-tax income forecast (predTAXF). For example, the coefficient estimates of the intersection variables (UE*predTAXE) are 0.826 and 0.714 , respectively, for the dependent variables (RET_vw and RET_ew, respectively). These results indicate that the analysts' pre-tax income forecast plays an important role in enhancing reliability in the capital market. That is, if an implicit tax forecast plays a role in raising the investor's confidence in analysts' earnings forecasts, the stock price reaction to unexpected earnings will be incrementally noticeable when an analyst provides both pre-tax income and earnings forecasts. From the findings in Table 6, we can conclude that $\mathrm{H} 2$ is also consistently supported.

Table 6: Value Relevance of Analysts' Implied Tax Forecast

\begin{tabular}{|c|c|c|c|}
\hline Variables & Prediction & $\begin{array}{c}\text { Model 1 } \\
\text { (RET_vw) }\end{array}$ & $\begin{array}{c}\text { Model } 2 \\
\text { (RET_ew) }\end{array}$ \\
\hline \multirow{2}{*}{ Intercept } & \multirow{2}{*}{$+/-$} & $0.158^{\star \star \star}$ & $0.173^{\star \star \star}$ \\
\hline & & $(4.329)$ & $(4.749)$ \\
\hline \multirow{2}{*}{ UE } & \multirow[b]{2}{*}{+} & $1.113^{\star \star \star}$ & $1.177^{\star \star \star}$ \\
\hline & & $(4.659)$ & $(4.919)$ \\
\hline \multirow{2}{*}{ predTAXF } & \multirow{2}{*}{$+/-$} & -0.041 & -0.068 \\
\hline & & $(-0.925)$ & $(-1.533)$ \\
\hline \multirow{2}{*}{ UE*predTAXF } & \multirow{2}{*}{+} & $0.826^{\star \star *}$ & $0.714^{\star \star}$ \\
\hline & & (2.592) & (2.237) \\
\hline \multicolumn{2}{|l|}{$\mathrm{N}$} & 2,972 & 2,972 \\
\hline \multicolumn{2}{|l|}{ Adj. $R^{2}$} & 0.140 & 0.136 \\
\hline \multicolumn{2}{|l|}{ F-value } & $161.210^{\star \star *}$ & $156.773^{\star \star \star}$ \\
\hline
\end{tabular}

1) The sample consists of 2,972 publicly traded companies in Korea with financial analyst forecasts. Refer to Eq. (1) \& (2) for the variable definitions. * ${ }^{* *}$, and ${ }^{* * *}$ represent significance at a two-sided $10 \%$, $5 \%$, and $1 \%$ level (two-sided), respectively. 


\section{Conclusion}

This study examines the effects of the complexity of taxrelated information on the issuance of analysts' pre-tax income forecasts and their value relevance. When analysts issue pre-tax income forecasts with earnings, they implicitly provide income tax expense information (Baik et al. 2016). Using 2,329 firm-year sample spanning 2005 to 2014, we provide several findings.

First, analysts systematically provide pre-tax income forecasts by considering tax-related information complexity. Specifically, our tests show that analysts tend to provide investors with pre-tax income forecasts (implicitly inferred as tax expenses forecast) for firms with less complex taxrelated information in financial statements. Second, we observe an incremental impact in the coefficient estimate of unexpected earnings to abnormal return, which implies that analysts' pre-tax income forecasts play an important role in enhancing reliability in the capital market. Third, two additional analyses show that the incremental impact on ERC of implicit tax forecasts is mainly significant for high complexity of a tax-related information environment.

From our findings, we can infer that when analysts provide additional tax-related forecasts to the capital market, investors rely more on such information because they attribute greater credibility to the information on future performance supplied by analysts. We thus contribute to extant literature by providing empirical evidence to show that analysts practice discriminatory decision-making by considering the information environment in their forecasts and information usefulness of the implicit tax forecast.

\section{References}

Ali, A., \& Hwang, L. (2000). Country-specific factors related to financial reporting and the relevance of accounting data. Journal of Accounting Research, 30(1), $1-21$.

Amir, E., \& Sougiannis, T. (1999). Analysts' interpretation and investors' valuation of tax carryforwards. Contemporary Accounting Research, 16(1), 1-33.

Ayers, B., Jiang, J., \& Laplante, S. (2009). Taxable income as a performance measure: The effects of tax planning and earnings quality. Contemporary Accounting Research, 26(1), 15-54.

Baik, B., Kim, K., Morton, R., \& Roh, Y. (2016). Analysts' pre-tax income forecasts and the tax expense anomaly. Review of Accounting Studies, 21(2), 559-595.

Bettman, J., Johnson, E., \& Payne, J. (1990). A componential analysis of cognitive effort in choice. Organizational Behavior and Human Decision Processes, 45(1), 111-140.

Bhushan, R. (1989). Firm characteristics and analyst following. Journal of Accounting and Economics, 11(2/3), 255-274.
Bratten, B., Gleason, C. A., Larocque, S. A., \& Mills, L. F. (2017). Forecasting taxes: New evidence from analysts. The Accounting Review, 92(3), 1-29.

Call, A., Chen, S., \& Tong, Y. (2009). Are analysts' earnings forecasts more accurate when accompanied by cash flow forecasts? Review of Accounting Studies, 14(2/3), 358391.

Chae, S., \& Ryu, H. (2018). The relationship between corporate social responsibilities and financial reporting quality: Focusing on distribution \& service companies. Journal of Distribution Science, 16(10), 77-82.

Collins, D., \& Kothari, S. (1989). An analysis of intertemporal and cross-sectional determinants of earnings response coefficients. Journal of Accounting and Economics, 11(2/3), 143-181.

Cook, K. A., Huston, G. R., \& Omer, T. (2008). Earnings management through effective tax rates: The effects of tax-planning investment and the Sarbanes-Oxley Act of 2002. Contemporary Accounting Research, 25(2), 447471.

DeFond, M. L., \& Hung, M. (2003). An empirical analysis of analysts' cash flow forecasts. Journal of Accounting and Economics, 35(1), 73-100.

Dhaliwal, D. S., Gleason, C. A., \& Mills, L. F. (2004). Lastchance earnings management: Using the tax expense to meet analysts' forecasts. Contemporary Accounting Research, 21(2), 431-459.

Dhaliwal, D., Lee, H. S., Pincus, M., \& Steele, L. (2017). Taxable income and firm risk. Journal of the American Taxation Association, 39(1), 1-24.

Gleason, C., \& Mills, L. (2008). Evidence of differing market responses to meeting or beating targets through tax expense decreases. Review of Accounting Studies, 13(2/3), 295-318.

Gupta, S., Laux, R. C., \& Lynch, D. P. (2016). Do firms use tax reserves to meet analysts' forecasts? Evidence from the pre- and post-FIN 48 periods. Contemporary Accounting Research, 33(3), 1044-1074.

Heckman, J. J. (1978). Dummy endogenous variables in a simultaneous equation system. Econometrica, 46(6), 931-959.

Hanlon, M., Laplante, S., \& Shevlin, T. (2005). Evidence on the possible information loss of conforming book income and taxable income. Journal of Law and Economics, 48(2), 407-442.

Hanlon, M., Maydew, E. L., \& Shevlin, T. (2006). An unintended consequence of book-tax conformity: A loss of earnings informativeness. Journal of Accounting and Economics, 46(2/3), 294-311.

Henry, E. (2018). The information content of tax expense: A discount rate explanation. Contemporary Accounting Research, 35(4), 1917-1940.

Hirst D., \& Hopkins, P. (1998). Comprehensive income reporting and analysts' valuation judgement. Journal of Accounting Research, 36(supp), 47-75.

Jeong, K., \& Park, C. (2016). The effect of corporate social responsibilities on the quality of corporate reporting. 
Journal of Distribution Science, 14(6), 75-80.

Joos, P., \& Lang, M. (1994). The effects of accounting diversity: Evidence from the European Union. Journal of Accounting Research, 32(supp), 141-168.

Kothari, S. P. (2001). Capital markets research in accounting. Journal of Accounting and Economics, 31(1), 105-231.

Kormendi, R., \& Lipe, R. (1987). Earnings innovations, earnings persistence and stock returns. Journal of Business, 60(3), 323-345.

Lev, B., \& Nissim, D. (2004). Taxable income, future earnings, and equity values. The Accounting Review, 79(4), 1039-1074.

Lee, B., \& Lee, S. (2018). A study on financial ratio and prediction of financial distress in financial markets. Journal of Distribution Science, 16(11), 21-27.

McEwen, R., \& Hunton, J. (1999). Is analyst forecast accuracy associated with accounting information use? Accounting Horizons, 13(1), 1-16.

McNichols, M., \& O’Brien, P. (1997). Self-selection and analyst coverage. Journal of Accounting Research, 35(supp), 167-199.

O’Brien, P., \& Bhushan, R. (1990). Analyst following and institutional ownership. Journal of Accounting Research, 28(supp), 55-76.

Park, H., \& Yoo, Y. (2019). Differences among credit rating agencies and the information environment. The Journal of Asian Finance, Economics and Business, 6(2), 25-32.

Payne, J. (1976). Task complexity and contingent processing in decision making: An information search and protocol analysis. Organizational Behavior and Human Performance, 16(2), 366-387.

Plumlee, M. A. (2003). The effect of information complexity on analysts' use of that information. The Accounting Review, 78(1), 275-296.

Radhakrishnan, S., \& Wu, S. L. (2014). Analysts' cash flow forecasts and accrual mispricing. Contemporary
Accounting Research, 31(4), 1191-1219.

Shane, P. B., \& Stock, T. (2006). Security analyst and stock market efficiency in anticipating tax-motivated income shifting. The Accounting Review 81(1), 227-250.

Thomas, J., \& Zhang, F. X. (2011). Tax expense momentum. Journal of Accounting Research, 49(3), 791-821.

Weber, D. P. (2009). Do analysts and investors fully appreciate the implications of book-tax differences for future earnings? Contemporary Accounting Research, 26(4), 1175-1206.

\section{Appendix}

A. Calculating Corporate Taxable Income in the Korean Tax System

The following table shows the process of calculating corporate taxable income according to Korea tax act. Differences included in 'Addition' or 'Deduction' are classified as either temporary or permanent differences.

\begin{tabular}{|c|c|}
\hline $\begin{array}{l}\text { Net income(loss), (Income Statement) } \\
\text { (+) Tax expenses (Income Statement) }\end{array}$ & $\begin{array}{c}\mathbf{X X X} \\
(+) \mathrm{XXX}\end{array}$ \\
\hline Pre-tax income(Income Statement, A) & XXX \\
\hline Addition (B): & \\
\hline $\begin{array}{l}\text { (1) Revenue(gain) that is accepted only in the } \\
\text { tax act [Case I] }\end{array}$ & (+)XXX \\
\hline $\begin{array}{l}\text { Expenses(loss) that it is acceptable in the } \\
\text { tax act less than those in the GAAP [Case II] }\end{array}$ & \\
\hline Deduction (C): & \\
\hline $\begin{array}{l}\text { (1) Revenue(gain) which is not accepted only } \\
\text { in the tax act [Case III] }\end{array}$ & (-) XXX \\
\hline $\begin{array}{l}\text { (2) Revenue(gain) that it is acceptable in the } \\
\text { tax act less than those in the GAAP [Case IV] }\end{array}$ & \\
\hline Corporate Taxable Income $($ loss $),(D=A+B-C)$ & XXX \\
\hline
\end{tabular}

